\title{
Central effects of thyronamines on glucose metabolism in rats
}

\author{
Lars P Klieverik', Ewout Foppen ${ }^{1,3}$, Mariëtte T Ackermans ${ }^{2}$, Mireille J Serlie', Hans P Sauerwein ${ }^{1}$, \\ Thomas S Scanlan ${ }^{4}$, David K Grandy ${ }^{4}$, Eric Fliers ${ }^{1, *}$ and Andries Kalsbeek ${ }^{1,3, *}$
}

Laboratory of Endocrinology, Departments of ${ }^{1}$ Endocrinology and Metabolism and ${ }^{2}$ Clinical Chemistry, Academic Medical Center, University of Amsterdam, F5-162, 1105 AZ Amsterdam, The Netherlands

${ }^{3}$ Netherlands Institute for Neuroscience, 1105 AZ Amsterdam, The Netherlands

${ }^{4}$ Department of Physiology and Pharmacology, School of Medicine, Oregon Health and Science University, Portland, Oregon 97239-3098, USA

(Correspondence should be addressed to L P Klieverik; Email: I.p.klieverik@amc.nl)

*(E Fliers and A Kalsbeek are joint senior authors)

\begin{abstract}
Thyronamines are naturally occurring, chemical relatives of thyroid hormone. Systemic administration of synthetic 3-iodothyronamine $\left(\mathrm{T}_{1} \mathrm{AM}\right)$ and - to a lesser extent thyronamine $\left(\mathrm{T}_{0} \mathrm{AM}\right)$, leads to acute bradycardia, hypothermia, decreased metabolic rate, and hyperglycemia. This profile led us to hypothesize that the central nervous system is among the principal targets of thyronamines. We investigated whether a low dose i.c.v. infusion of synthetic thyronamines recapitulates the changes in glucose metabolism that occur following i.p. thyronamine administration. Plasma glucose, glucoregulatory hormones, and endogenous glucose production (EGP) using stable isotope dilution were monitored in rats before and $120 \mathrm{~min}$ after an i.p. $(50 \mathrm{mg} / \mathrm{kg})$ or i.c.v. $(0.5 \mathrm{mg} / \mathrm{kg})$ bolus infusion of $\mathrm{T}_{1} \mathrm{AM}, \mathrm{T}_{0} \mathrm{AM}$, or vehicle. To identify the peripheral effects of centrally administered thyronamines, drug-naive rats were also infused intravenously with low dose
\end{abstract}

$(0 \cdot 5 \mathrm{mg} / \mathrm{kg})$ thyronamines. Systemic $\mathrm{T}_{1} \mathrm{AM}$ rapidly increased EGP and plasma glucose, increased plasma glucagon, and corticosterone, but failed to change plasma insulin. Compared with i.p.-administered $\mathrm{T}_{1} \mathrm{AM}$, a 100-fold lower dose administered centrally induced a more pronounced acute EGP increase and hyperglucagonemia while plasma insulin tended to decrease. Both systemic and central infusions of $\mathrm{T}_{0} \mathrm{AM}$ caused smaller increases in EGP, plasma glucose, and glucagon compared with $\mathrm{T}_{1} \mathrm{AM}$. Neither $\mathrm{T}_{1} \mathrm{AM}$ nor $\mathrm{T}_{0} \mathrm{AM}$ influenced any of these parameters upon low dose i.v. administration. We conclude that central administration of low-dose thyronamines suffices to induce the acute alterations in glucoregulatory hormones and glucose metabolism following systemic thyronamine infusion. Our data indicate that thyronamines can act centrally to modulate glucose metabolism.

Journal of Endocrinology (2009) 201, 377-386

\section{Introduction}

Thyronamines are a group of naturally occurring, chemical relatives of thyroid hormone (TH) with pronounced and rapid physiologic effects (Scanlan et al. 2004). Two representatives of the thyronamines, 3-iodothyronamine $\left(\mathrm{T}_{1} \mathrm{AM}\right)$ and thyronamine $\left(\mathrm{T}_{0} \mathrm{AM}\right)$, have been extracted from rat and mouse brain, heart, liver, and blood. $\mathrm{T}_{1} \mathrm{AM}$ and $\mathrm{T}_{0} \mathrm{AM}$ can theoretically be derived from iodothyronines thyroxine $\left(\mathrm{T}_{4}\right), 3,3^{\prime}, 5$-triiodothyronine $\left(\mathrm{T}_{3}\right)$, and/or $3,3^{\prime}$, $5^{\prime}$-triiodothyronine (reverse $\mathrm{T}_{3}$ ) by removal of the carboxylate group on the $\beta$-alanine side chain in addition to deiodination. Indeed, thyronamines have recently been identified as isoenzyme-specific substrates of the iodothyronine deiodinases type 1, 2, and 3 (Piehl et al. 2008). T 1 AM and, to a lesser extent, $\mathrm{T}_{0} \mathrm{AM}$ are potent in vitro agonists of the trace amineassociated receptor type 1 (TAAR1; Scanlan et al. 2004, Hart et al. 2006), a Gs protein-coupled membrane receptor with a broad expression profile (Grandy 2007). In rodents and humans, high levels of TAAR 1 expression are found in liver, kidney, gastrointestinal tract, pancreas, heart, and many areas of the brain (Borowsky et al. 2001, Bunzow et al. 2001). Moreover, $\mathrm{T}_{1} \mathrm{AM}$ has the potential to act as an adrenergic receptor $\alpha 2(\mathrm{AR} \alpha 2)$ agonist in the mouse, explaining in part the decrease in insulin secretion by pancreatic $\beta$-cells exposed to thyronamines (Regard et al. 2007).

When administered to rodents, $\mathrm{T}_{1} \mathrm{AM}$ and $\mathrm{T}_{0} \mathrm{AM}$ have striking effects on physiology. Within minutes after systemic administration, profound hypothermia, bradycardia, and decreased cardiac output occur. In addition, thyronamines rapidly induce metabolic alterations such as decreased metabolic rate and a dramatic shift to preferential lipid fuelling at the cost of carbohydrate oxidation (Scanlan et al. 2004, Braulke et al. 2007). These apparently non-genomic effects are thought to occur via binding to and activating membrane-bound $G$ protein-coupled receptors (GPCRs) such as TAAR1 and AR $\alpha 2$ (Liggett 2004, Scanlan et al. 2004). Furthermore, it has been proposed but not yet demonstrated that THs can be converted to thyronamines by enzymatic deiodination and decarboxylation. Since most 
actions of $T_{1} A M$ and $T_{0} A M$ are opposite in direction to the bioactive $\mathrm{TH} \mathrm{T}_{3}$, thyronamines have been hypothesized to play a role in fine-tuning and/or antagonizing $\mathrm{T}_{3}$ actions on a moment-to-moment timescale (Liggett 2004, Weatherman 2007).

The brain, in particular the hypothalamus, regulates most of the processes affected by thyronamines (body temperature, cardiac function, and energy metabolism). Moreover, a principal role in regulating hepatic glucose metabolism has recently emerged for the hypothalamus (Obici et al. 2002, Kalsbeek et al. 2004, Pocai et al. 2005). As $T_{1} A M$ and $T_{0} A M$ are present in rat brain, we hypothesized that these novel compounds could affect glucose metabolism via actions in the central nervous system (CNS).

In the present study, we tested the hypothesis that thyronamines act centrally to induce changes in glucose metabolism using stable isotope dilution and three different routes of administration: systemic (i.p.), central (i.c.v.), and i.v. in rats. Our results are consistent with the interpretation that $\mathrm{T}_{1} \mathrm{AM}$ and $\mathrm{T}_{0} \mathrm{AM}$ can act centrally to recapitulate the changes in glucose metabolism that occur following systemic thyronamine administration.

\section{Materials and Methods}

\section{Animals}

Male Wistar rats (Harlan, Horst, The Netherlands) between 350 and $400 \mathrm{~g}$ body weight (BW), housed under constant conditions of temperature $\left(21 \pm 1{ }^{\circ} \mathrm{C}\right)$ and humidity $(60 \pm 2 \%)$ with a $12 \mathrm{~h}$ light: $12 \mathrm{~h}$ darkness schedule (lights on at $0700 \mathrm{~h}$ ), were used in all experiments. Food and drinking water were available ad libitum. All of the following experiments were conducted with the approval of the Animal Care Committee of the Royal Netherlands Academy of Arts and Sciences.

\section{$T_{1} A M$ and $T_{0} A M$}

$\mathrm{T}_{1} \mathrm{AM}-\mathrm{HCl}(391 \mathrm{~g} / \mathrm{mol})$ and $\mathrm{T}_{0} \mathrm{AM}-\mathrm{HCl}(264 \mathrm{~g} / \mathrm{mol})$ were synthesized as previously reported (Hart et al. 2006) and dissolved in 20\% DMSO and $80 \%$ saline (vehicle) at a concentration of $40 \mathrm{mg} / \mathrm{ml}$.

\section{Experimental groups}

Two independent studies were performed. For the first study, permanent jugular vein and carotid artery cannulae were placed in rats $(n=22)$ under anesthesia (see below). Animals were allowed to recover from the surgery for 8 days prior to any further manipulations. Each rat thus cannulated received an i.p. bolus infusion of $50 \mathrm{mg} / \mathrm{kg}$ of $\mathrm{T}_{1} \mathrm{AM}(n=7), 50 \mathrm{mg} / \mathrm{kg}$ of $\mathrm{T}_{0} \mathrm{AM}(n=8)$, or an equal volume $(500 \mu \mathrm{l})$ of vehicle $(n=7)$. For the second study, rats $(n=31)$ were equipped with a guide cannula placed into the left lateral cerebral ventricle in addition to the carotid artery and jugular vein cannulae. Rats thus cannulated received an i.c.v. 100-fold lower dose $(0 \cdot 5 \mathrm{mg} / \mathrm{kg})$ of either $\mathrm{T}_{1} \mathrm{AM}(n=9), \mathrm{T}_{0} \mathrm{AM}(n=8)$, or DMSO-saline vehicle $(n=8)$ in a volume of $4 \mu$. To control for the possibility that any observed effect of the i.c.v.-infused thyronamines was somehow due to spillover into the circulation, an additional group of cannulated rats was infused intravenously with $0.5 \mathrm{mg} / \mathrm{kg} \mathrm{T} \mathrm{T}_{1} \mathrm{AM}(n=3)$ and $\mathrm{T}_{0} \mathrm{AM}(n=3)$ in a volume of $500 \mu \mathrm{l}$. In both of these experiments, before and $120 \mathrm{~min}$ after i.p. or i.c.v. bolus infusion, isotope dilution and blood sampling were conducted to permit measurement of endogenous glucose production (EGP), and the concentration of plasma glucose, insulin, glucagon, corticosterone, thyroid stimulating hormone (TSH), $\mathrm{T}_{3}$ and $\mathrm{T}_{4}$ concentrations.

\section{Surgery}

Animals were anaesthetized using a mixture of Hypnorm (Janssen; 0.05 ml/100 g BW, i.m.) and Dormicum (Roche; $0.04 \mathrm{ml} / 100 \mathrm{~g} \mathrm{BW}$, s.c). Vascular and i.c.v. cannulae were fixed with dental cement to four stainless-steel screws inserted into the skull. Post-operative care was provided by s.c. injection of $0.01 \mathrm{ml} / 100 \mathrm{~g} \mathrm{BW}$ of Temgesic (Schering-Plough, Utrecht, The Netherlands). In all animals, an intra-atrial silicone cannula was implanted through the right jugular vein and a second silicone cannula was placed in the left carotid artery for isotope infusion and blood sampling as described previously (Klieverik et al. 2008). For the second study, stainless-steel i.c.v. cannulae were implanted into the left cerebral ventricle using the following stereotaxic coordinates: anteroposterior: $-0.8 \mathrm{~mm}$; lateral: $+2.0 \mathrm{~mm}$; ventral: $-3.2 \mathrm{~mm}$, with the toothbar set at $-3.4 \mathrm{~mm}$. Guide cannula placement was confirmed by dye ( $4 \mu \mathrm{l}$ of ethylene blue) injection and inspection post-mortem. Only animals that showed staining of the left lateral cerebral ventricle and third cerebral ventricle were included in the final analysis.

\section{Stable isotope dilution and systemic versus central thyronamine} administration

Eight days post-surgery, stable isotope dilution was performed in combination with the administration of synthetic thyronamines. Animals weighed between 335 and $380 \mathrm{~g}$. BW increased in all groups during the 3 days preceding the experimental infusions, indicating recovery from surgery and a positive energy balance. One day before the experimental infusions, rats were connected to a metal collar to which polyethylene tubing (for blood sampling and infusion) was attached and kept out of reach of the animals by a counterbalanced beam. This permitted all subsequent manipulations to be performed outside the cages without handling the animals (Klieverik et al. 2008). For determining basal plasma concentrations of TSH, $\mathrm{T}_{3}$, and $\mathrm{T}_{4}$, a blood sample was obtained at $1400 \mathrm{~h}$. On the day 
of thyronamine administration, food was removed from the cages $4 \mathrm{~h}(\sim 0830 \mathrm{~h})$ before the first basal measurements. At $\sim 1100 \mathrm{~h}$, a blood sample was taken $(200 \mu \mathrm{l}$, $t=-110 \mathrm{~min})$ for determination of background isotopic enrichment. Subsequently, a primed $(8.0 \mu \mathrm{mol}$ in $5 \mathrm{~min})$ continuous $(16 \cdot 6 \mu \mathrm{mol} / \mathrm{h})$ infusion of the stable isotope tracer $\left[6,6-{ }^{2} \mathrm{H}_{2}\right]$-glucose $(>99 \%$ enriched; Cambridge Isotope Laboratories, Cambridge, MA, USA) was started using an infusion pump (Harvard Apparatus, Holliston, MA, USA). After an equilibration period of $90 \mathrm{~min}$, additional blood samples $(200 \mu \mathrm{l})$ were obtained for the determination of basal plasma glucose, isotopic enrichment $(t=-20,-10$ and $0 \mathrm{~min})$, plasma corticosterone $(t=-20$ and $0 \mathrm{~min})$, insulin, and glucagon $(t=0 \mathrm{~min})$ concentrations.

After the $t=0$ blood sample, in study 1 , animals received an i.p. bolus of either $T_{1} A M, T_{0} A M(50 \mathrm{mg} / \mathrm{kg}$ in $500 \mu \mathrm{l})$, or vehicle. In study 2 , again after the $t=0$ blood sample, animals received an i.c.v. bolus infusion of either $T_{1} A M$, $\mathrm{T}_{0} \mathrm{AM}(0.5 \mathrm{mg} / \mathrm{kg}$ in $4 \mu \mathrm{l})$, or vehicle delivered through the i.c.v. cannula in $105 \mathrm{~s}$ using a Hamilton syringe. After i.p. or i.c.v. bolus infusion, blood samples were obtained for measurement of glucose concentration, isotopic enrichment $(5,10,20,30,45,60,75,90$, and $120 \mathrm{~min})$, plasma corticosterone $(t=10,20,30,60$, and $120 \mathrm{~min})$, plasma insulin, glucagon ( $t=10,60$ and $120 \mathrm{~min})$, and plasma TSH, $\mathrm{T}_{3}$, and $\mathrm{T}_{4}$ concentrations $(t=120 \mathrm{~min})$.

\section{Plasma hormone and isotope analyses}

Plasma glucose concentration was determined in triplicate by a glucose oxidase method (Boehringer Mannheim). Plasma glucagon and corticosterone were measured using a commercially available RIA (LINCO Research, St Charles, MO, USA and ICN Biomedicals, Costa Mesa, CA, USA respectively). Plasma concentrations of $\mathrm{T}_{3}$ and $\mathrm{T}_{4}$ were determined by an in-house RIA (Kalsbeek et al. 2000), with inter- and intra-assay variation coefficients (CV) of 78 and $3-4 \%\left(\mathrm{~T}_{3}\right)$, and $3-6$ and $2-4 \%\left(\mathrm{~T}_{4}\right)$ respectively. Detection limits for $\mathrm{T}_{3}$ and $\mathrm{T}_{4}$ were 0.3 and $5 \mathrm{nmol} / 1$ respectively. Plasma TSH concentrations were determined by a chemiluminescent immunoassay (Immulite 2000, Diagnostic Products Corp., Los Angeles, CA, USA) using a rat-specific standard. The inter- and intra-assay CV's for TSH were $<4$ and $2 \%$ at $\pm 3.5 \mathrm{mU} / 1$ respectively with a detection limit of $0 \cdot 40 \mathrm{mU} / \mathrm{l}$. Plasma insulin was measured by a commercially available ELISA (Mercodia, Uppsala, Sweden; Ackermans et al. 2008). The inter- and intra-assay CV's were 4 and $2 \%$, detection limit 13 pmol/l. All samples were measured in duplicate, i.e. two tubes were analyzed per plasma sample. Glucose enrichment was measured as previously described (Ackermans et al. 2001). The $\left[6,6-{ }^{2} \mathrm{H}_{2}\right]$-glucose enrichment (tracer/tracee ratio) interassay $\mathrm{CV}$ was $1 \%$, the intra-assay $\mathrm{CV} 1 \%$, and the detection limit $0 \cdot 04 \%$.

\section{Calculations and statistical analysis}

EGP was calculated from isotope enrichment and plasma glucose concentration using modified forms of steady-state (basal) and non-steady-state (after thyronamine infusion) Steele equations (Steele 1959). Data were analyzed by twoway ANOVA with repeated measurements, with treatment group ( $\mathrm{T}_{1} \mathrm{AM}, \mathrm{T}_{0} \mathrm{AM}$, or $\mathrm{Veh}$ ) and time as dependent factors. Significance was defined at $P<0.05$ using paired $t$-tests (i.e. within treatment groups) and independent $t$-tests (i.e. between treatment groups) to identify experimental groups that differed significantly. The SPSS statistical software program version 16.0 (SPSS Inc., Chicago, IL, USA) was used for statistical analysis. Data are presented as mean \pm s.E.M.

\section{Results}

In two independent studies, eight groups of rats were investigated. In the first study, rats received an i.p. bolus infusion of either $\mathrm{T}_{1} \mathrm{AM}(50 \mathrm{mg} / \mathrm{kg}, \quad n=7), \mathrm{T}_{0} \mathrm{AM}$ $(50 \mathrm{mg} / \mathrm{kg}, n=8)$, or vehicle $(n=7)$. In the second study, rats were intracerebroventricularly infused with a 100 -fold lower dose (i.e. $0.5 \mathrm{mg} / \mathrm{kg}$ ) of either $\mathrm{T}_{1} \mathrm{AM}(n=9), \mathrm{T}_{0} \mathrm{AM}$ $(n=8)$, or vehicle $(n=8)$. To address the possibility that any physiologic response observed following i.c.v. infusion of the thyronamines was due to the peripheral action of drug that spilled over into the circulation, two additional groups of animals were intravenously infused with $0.5 \mathrm{mg} / \mathrm{kg}$ of $\mathrm{T}_{1} \mathrm{AM}$ $(n=3)$ or $0.5 \mathrm{mg} / \mathrm{kg}$ of $\mathrm{T}_{0} \mathrm{AM}(n=3)$.

\section{Study \#1: systemic thyronamine infusion}

Rats injected i.p. with $50 \mathrm{mg} / \mathrm{kg} \mathrm{T}_{1} \mathrm{AM}$ or $50 \mathrm{mg} / \mathrm{kg} \mathrm{T}_{0} \mathrm{AM}$ exhibited a behavioral phenotype as described previously (Scanlan et al. 2004). Interestingly, the animals injected with $\mathrm{T}_{1} \mathrm{AM}$ displayed the more robust phenotype even though the dose (on a per mole basis) was approximately half that of $\mathrm{T}_{0} \mathrm{AM}$.

\section{Glucose homeostasis: plasma concentration and endogenous production Systemic infusion of either} $\mathrm{T}_{1} \mathrm{AM}$ or $\mathrm{T}_{0} \mathrm{AM}$ by the i.p. route of administration induced a rapid and significant increase in plasma glucose concentration (Fig. 1a). The onset and magnitude of this effect was similar for the two compounds until 45 min post-infusion when the effect of $\mathrm{T}_{0} \mathrm{AM}$ apparently plateaued, while the $\mathrm{T}_{1} \mathrm{AM}$-induced hyperglycemia continued to develop eventually reaching a maximum $371 \pm 27 \%$ of basal values $120 \mathrm{~min}$ after infusion.

Within $10 \mathrm{~min}$ of receiving an i.p. bolus of $\mathrm{T}_{1} \mathrm{AM}$, the EGP increased to $143 \pm 3 \%$ of basal values $(P=0.001$ versus Veh; Fig. 1b), which was sustained for the duration of the experiment. Similarly, i.p. administration of $\mathrm{T}_{0} \mathrm{AM}$ rapidly increased EGP, reaching a maximum of $158 \pm 16 \%$ of basal values after $20 \min (P=0.032$ versus Veh). Forty-five minutes after injection with $\mathrm{T}_{0} \mathrm{AM}$, EGP gradually returned to basal values by $t=120 \mathrm{~min}$. 

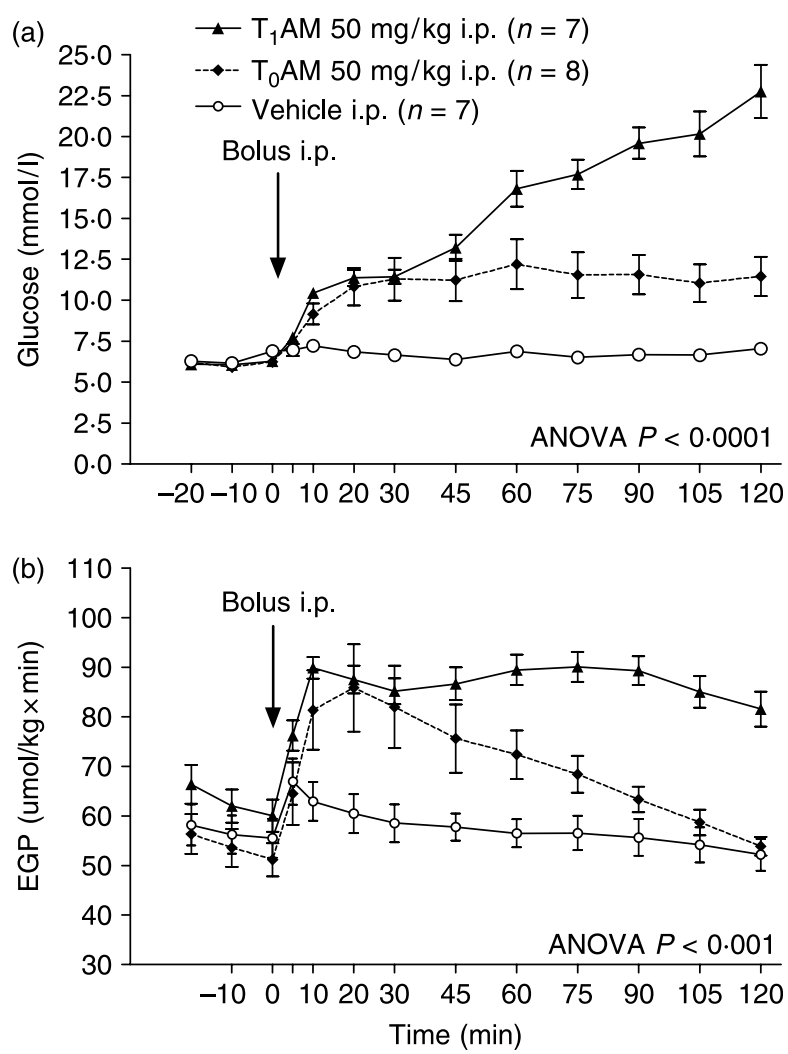

Figure 1 (a) Plasma glucose concentrations before and after i.p. bolus infusion of $\mathrm{T}_{1} \mathrm{AM}, \mathrm{T}_{0} \mathrm{AM}$, or vehicle. Note that from $t=10 \mathrm{~min}$, glucose concentration is higher in $\mathrm{T}_{1} \mathrm{AM}$ - and $\mathrm{T}_{0} \mathrm{AM}$ treated animals when compared with vehicle rats $(P<0 \cdot 05)$. From $t=60$, glucose concentration is higher in $\mathrm{T}_{1} \mathrm{AM}$ when compared with $\mathrm{T}_{0} \mathrm{AM}$-treated rats $(P<0 \cdot 05)$. ANOVA RM factor time $P<0 \cdot 0001$, time $\times$ group $P<0 \cdot 0001$, and group $P<0 \cdot 0001$. (b) Endogenous glucose production (EGP) before and after i.p. bolus infusion of $\mathrm{T}_{1} \mathrm{AM}, \mathrm{T}_{0} \mathrm{AM}$, or vehicle. From $t=10$ and $t=20$, EGP is higher in $\mathrm{T}_{1} \mathrm{AM}$ - and $\mathrm{T}_{0} \mathrm{AM}$-infused rats respectively, when compared with vehicle $(P<0 \cdot 05)$. From $t=60$, EGP is lower in $\mathrm{T}_{0} \mathrm{AM}$ relative to $\mathrm{T}_{1} \mathrm{AM}$-treated animals $(P<0 \cdot 05)$. From $t=90$, $E G P$ in $T_{0} A M$-treated rats is not different from vehicle rats. ANOVA RM factor time $P<0 \cdot 0001$, time $\times$ group $P<0 \cdot 0001$, and group $P=0.001$.

Glucoregulatory hormones Given the profound effect of $\mathrm{T}_{1} \mathrm{AM}$ and $\mathrm{T}_{0} \mathrm{AM}$ on plasma glucose and EGP, we characterized the status of three glucoregulatory hormones: insulin; glucagon; and corticosterone (Fig. 2). Surprisingly, even though $\mathrm{T}_{1} \mathrm{AM}$ and $\mathrm{T}_{0} \mathrm{AM}(50 \mathrm{mg} / \mathrm{kg}$, i.p.) produced hyperglycemia and elevated EGP, plasma insulin concentrations were unchanged relative to plasma from vehicleinjected rats (Fig. 2a). By contrast, plasma glucagon concentrations were significantly increased within $10 \mathrm{~min}$ of either $\mathrm{T}_{1} \mathrm{AM}$ or $\mathrm{T}_{0} \mathrm{AM}$ administration (Fig. 2b). However, by $60 \mathrm{~min}$ post-injection, the time-effect profiles of the two compounds had begun to diverge with $\mathrm{T}_{0} \mathrm{AM}$ 's effect reaching a plateau at $240 \%\left(P=0.007 \mathrm{~T}_{0} \mathrm{AM}\right.$ versus $\mathrm{Veh}$, $t=60)$ of basal levels, while $\mathrm{T}_{1}$ AM's effect continued to develop for the duration of the experiment $(447 \pm 44 \%$ of basal values at $120 \mathrm{~min}, P<0.0001 \mathrm{~T}_{1} \mathrm{AM}$ versus $\mathrm{Veh}$; Fig. 2b). Of note, the time-course profiles of plasma glucagon (Fig. 2b) and plasma glucose (Fig. 1a) in response to i.p. $T_{1} A M$ and $T_{0} A M$ were essentially superimposable.

Plasma corticosterone displayed a significant increase in response to both $T_{1} A M-$ and $T_{0} A M$-injected i.p., compared with vehicle-injected rats (Fig. 2c). $T_{1} A M$ infusion induced a maximal increase at $t=60 \mathrm{~min}(482 \pm 106$ vs $179 \pm 71 \%$ of basal levels at $t=60 \mathrm{~min}, \mathrm{~T}_{1} \mathrm{AM}$ versus Veh; $P=0.022$ ). $\mathrm{T}_{0} \mathrm{AM}$ infusion increased plasma corticosterone to a similar extent $(393 \pm 59$ vs $172 \pm 102 \%$ of basal levels at $t=120 \mathrm{~min}$, $\mathrm{T}_{0} \mathrm{AM}$ versus Veh; $P=0 \cdot 022$ ). At no time point was there a difference in the corticosterone response between $T_{1} A M-$ and $\mathrm{T}_{0} \mathrm{AM}$-infused groups.

Plasma $\mathrm{T}_{3}, \mathrm{~T}_{4}$, and TSH concentrations before and $120 \mathrm{~min}$ after i.p. $\mathrm{T}_{1} \mathrm{AM}, \mathrm{T}_{0} \mathrm{AM}$, and vehicle infusion are depicted in Table 1 . Within 120 min, both $\mathrm{T}_{4}$ and TSH levels were significantly decreased in response to i.p. $\mathrm{T}_{1} \mathrm{AM}$ or, to a larger extent, i.p. $T_{0} A M(50 \mathrm{mg} / \mathrm{kg})$. Intriguingly, $T_{3}$ levels were also decreased $120 \mathrm{~min}$ after i.p. $\mathrm{T}_{0} \mathrm{AM}(50 \mathrm{mg} / \mathrm{kg})$ when compared with vehicle-injected rats.

\section{Study \#2: central thyronamine infusion}

I.c.v. infusion of $0.5 \mathrm{mg} / \mathrm{kg} \mathrm{T}_{1} \mathrm{AM}$ or $\mathrm{T}_{0} \mathrm{AM}$ did not induce any of the phenotypical alterations observed after systemic thyronamine administration.

Glucose homeostasis: plasma concentration and endogenous production With an i.c.v. bolus infusion of $0.5 \mathrm{mg} / \mathrm{kg}, \mathrm{T}_{1} \mathrm{AM}$ plasma glucose concentration began to increase immediately (Fig. 3a) until it reached a maximum $199 \pm 13 \%$ of basal levels $30 \mathrm{~min}$ after infusion $(P<0 \cdot 0001$ versus Veh). During the next $90 \mathrm{~min}$, plasma glucose decreased slightly stabilizing at $\sim 163 \%$ of basal values. $\mathrm{T}_{0} \mathrm{AM} \quad(0.5 \mathrm{mg} / \mathrm{kg}$, i.c.v. $)$ significantly elevated plasma glucose as well, but to a lesser degree than $\mathrm{T}_{1} \mathrm{AM}$ (maximum $134 \pm 6 \%$ at $t=45, P<0 \cdot 0001$ versus Veh; Fig. 3a).

$\mathrm{T}_{1} \mathrm{AM}(0.5 \mathrm{mg} / \mathrm{kg}$, i.c.v. $)$ induced a rapid and significant increase in EGP (Fig. 3b) by 10 min post-infusion reaching a maximum $178 \pm 16 \%$ of basal values at $30 \mathrm{~min}(P<0.0001$ versus Veh), which gradually decreased with time to $113 \pm 5 \%$ when the experiment was terminated at $t=120 \mathrm{~min}$. Although $\mathrm{T}_{0} \mathrm{AM}(0.5 \mathrm{mg} / \mathrm{kg}$, i.c.v. $)$ significantly increased EGP above basal levels $(P<0 \cdot 0001 ; t=0$ vs $t=10)$, its maximum effect $(20 \pm 9 \%$ increase at $t=20 ; P=0.069$ versus Veh) was approximately one-third of $\mathrm{T}_{1}$ AM's maximal effect (Fig. 3b).

Importantly, when $T_{1} A M$ or $T_{0} A M$ were infused intravenously at the dose that was used in the i.c.v. infusion experiments $\left(0.5 \mathrm{mg} / \mathrm{kg}, \mathrm{T}_{1} \mathrm{AM} n=3, \mathrm{~T}_{0} \mathrm{AM} n=3\right)$ neither thyronamine had any effect on plasma glucose concentrations, EGP, plasma insulin, nor glucagon at any time point when compared with basal values (data not shown). 
When the absolute changes in plasma glucose concentration produced by $0.5 \mathrm{mg} / \mathrm{kg} \mathrm{T}_{1} \mathrm{AM}$ i.c.v. and $50 \mathrm{mg} / \mathrm{kg}$ $\mathrm{T}_{1} \mathrm{AM}$ i.p. are compared over time, their profiles are practically superimposable for the first $30 \mathrm{~min}$ of exposure (Fig. 4a). Thereafter, they diverged as the systemic effect of $\mathrm{T}_{1} \mathrm{AM}$ continued to develop. Plotting the absolute values for EGP in response to $0.5 \mathrm{mg} / \mathrm{kg} \mathrm{T}_{1} \mathrm{AM}$ i.c.v. and $50 \mathrm{mg} / \mathrm{kg}$ $\mathrm{T}_{1} \mathrm{AM}$ i.p. revealed both routes of administration-produced identical profiles during the initial $20 \mathrm{~min}$ post-exposure
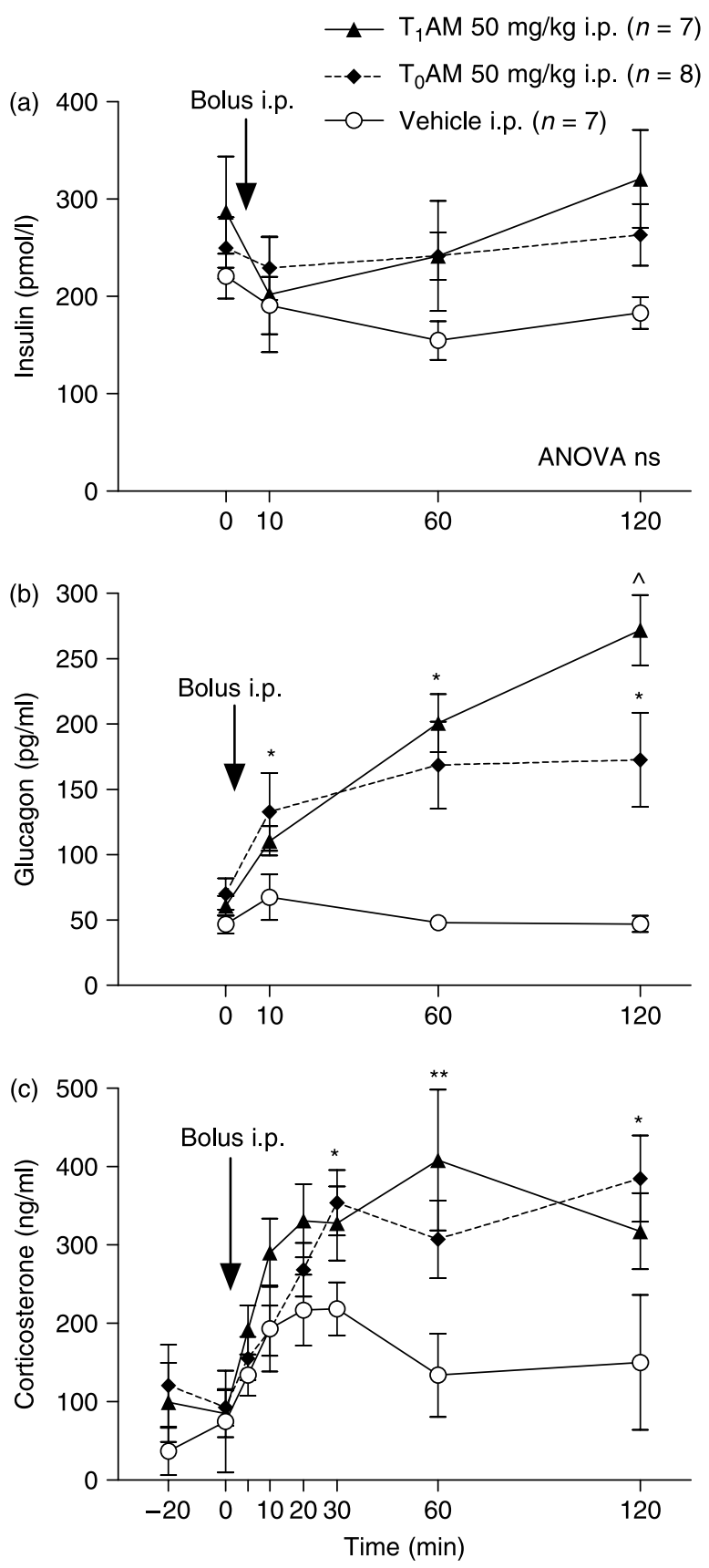

www.endocrinology-journals.org
(Fig. 4b). However, at $30 \mathrm{~min}$ thereafter, the magnitude of the EGP effect elicited by $T_{1} A M$ i.c.v. was significantly greater than the effect of $T_{1} A M$ i.p. (Fig. $4 b$ ).

Glucoregulatory hormones Similar to $T_{1} A M$ i.p. (Fig. 2a), neither $T_{1} A M-$ nor $T_{0} A M$-administered i.c.v. induced a significant change in plasma insulin content (Fig. 5a). Although there was a trend for insulin to decrease $10 \mathrm{~min}$ after i.c.v. infusion of $\mathrm{T}_{1} \mathrm{AM}$, this response failed to achieve statistical significance $(P=0 \cdot 063$; Fig. 5 a) .

Plasma glucagon increased by $155 \%$ (from $69 \pm 10$ to $176 \pm 20 \mathrm{pg} / \mathrm{ml}) 10 \mathrm{~min}$ after i.c.v. $\mathrm{T}_{1} \mathrm{AM}$ infusion $(P<0.0001$ versus Veh). During the same time period, $\mathrm{T}_{0} \mathrm{AM}$ i.c.v. also significantly increased plasma glucagon, but only by $58 \%(P=0.004$ versus $\mathrm{Veh})$. Interestingly, the magnitude of $\mathrm{T}_{1}$ AM's impact on circulating glucagon levels was dependent on the route of administration with i.c.v. infusion producing a greater effect in the first $10 \mathrm{~min}$ than i.p. administration $(108 \pm 21$ vs $50 \pm 11 \mathrm{pg} / \mathrm{ml}$ respectively; $P=0 \cdot 044)$. Unlike the sustained elevation that followed i.p. administration of either $\mathrm{T}_{1} \mathrm{AM}$ or $\mathrm{T}_{0} \mathrm{AM}$, plasma glucagon returned to basal levels within $60 \mathrm{~min}$ of infusing either compound i.c.v. (Fig. 5b).

Plasma corticosterone concentrations were significantly increased following i.c.v. infusion of either $0.5 \mathrm{mg} / \mathrm{kg} \mathrm{T}$ AM or $\mathrm{T}_{0} \mathrm{AM}$ (Fig. $5 \mathrm{c}$ ) with both treatments producing nearly equivalent maximum effects by $t=20 \mathrm{~min}$ post-injection (delta corticosterone $t=20$ vs $t=0 ; 6 \pm 44 \mathrm{ng} / \mathrm{ml}$ Veh i.c.v., $206 \pm 58 \mathrm{ng} / \mathrm{ml} \mathrm{T}_{1} \mathrm{AM}$ i.c.v., $296 \pm 49 \mathrm{ng} / \mathrm{ml} \mathrm{T}_{0} \mathrm{AM}$ i.c.v., $P=0.02 \mathrm{~T}_{1} \mathrm{AM}$ versus Veh, $P<0.0001 \mathrm{~T}_{0} \mathrm{AM}$ versus $V e h$ ).

Plasma $\mathrm{T}_{3}, \mathrm{~T}_{4}$, and TSH concentrations before and after central (i.c.v.) infusion of either $\mathrm{T}_{1} \mathrm{AM}, \mathrm{T}_{0} \mathrm{AM}$, or vehicle (saline-DMSO) infusion are shown in Table 2. Although plasma $\mathrm{T}_{3}, \mathrm{~T}_{4}$, and TSH were found to decrease in all treatment groups by $120 \mathrm{~min}$ post-i.c.v. bolus infusion, neither i.c.v. $T_{1} A M$ nor $T_{0} A M$ had a statistically significant effect on plasma $\mathrm{T}_{3}, \mathrm{~T}_{4}$, or TSH compared with vehicle i.c.v.

Figure 2 (a) Plasma insulin concentration before $(t=0)$ and after i.p. injection of $\mathrm{T}_{1} \mathrm{AM}, \mathrm{T}_{0} \mathrm{AM}$, or vehicle. ANOVA indicates no effects of time and no differences in insulin concentration between groups (ANOVA RM factor time $P=0 \cdot 556$, time $\times$ group $P=0 \cdot 735$, and group $P=0 \cdot 213)$. (b) Plasma glucagon concentration before $(t=0)$ and after i.p. injection of $\mathrm{T}_{1} \mathrm{AM}, \mathrm{T}_{0} \mathrm{AM}$, or vehicle. From $t=10$, glucagon is higher in both $T_{1} A M$ - and $T_{0} A M$-treated rats relative to vehicle rats $(* P<0 \cdot 05$ versus Veh). At $t=60$, glucagon concentration is higher in $T_{1} A M$ when compared with $T_{0} A M$-treated rats $\left({ }^{\wedge} P=0.05 \mathrm{~T}_{0} \mathrm{AM}\right.$ versus $\left.\mathrm{T}_{1} \mathrm{AM}\right)$. ANOVA RM factor time $P<0 \cdot 0001$, time $\times$ group $P<0 \cdot 0001$, and group $P=0 \cdot 001$. (c) Plasma corticosterone concentration before $(t=-20$ and $t=0 \mathrm{~min})$ and after ( $t=5-120 \mathrm{~min}$ ) i.p. injection of $\mathrm{T}_{1} \mathrm{AM}, \mathrm{T}_{0} \mathrm{AM}$, or vehicle. $\mathrm{T}_{0} \mathrm{AM}-$ treated animals have higher plasma corticosterone from $t=30$ and $\mathrm{T}_{1} \mathrm{AM}$-treated animals only on $t=60$ when compared with vehicle $\left({ }^{*} P<0.05\right.$ versus Veh). Note that at no time-point, plasma corticosterone between $\mathrm{T}_{1} \mathrm{AM}$ - and $\mathrm{T}_{0} \mathrm{AM}$-injected animals differs. ANOVA RM factor time $P<0 \cdot 0001$, time $\times$ group $P=0 \cdot 050$, and group $P=0 \cdot 030$. 
Table 1 Plasma thyroid hormone concentrations before (basal) and after (2 h) i.p. vehicle, $T_{1} A M$, and $T_{0} A M$ infusion

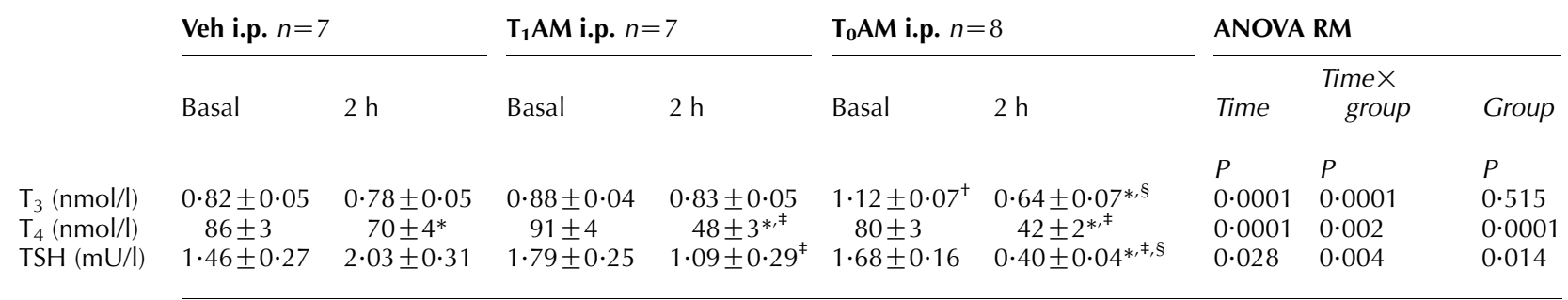

${ }^{*} P \leq 0.05$ versus basal value within the same group, ${ }^{+} P<0 \cdot 05$ versus Veh basal, ${ }^{\ddagger} P<0 \cdot 05$ versus Veh $2 \mathrm{~h},{ }^{\circledR} P<0.05$ versus $\mathrm{T}_{1} \mathrm{AM} 2 \mathrm{~h}$.

\section{Discussion}

In an effort to determine whether the thyronamines $\mathrm{T}_{1} \mathrm{AM}$ and $\mathrm{T}_{0} \mathrm{AM}$ can affect glucose homeostasis by acting directly on the brain, we compared their physiologic consequences following systemic and central administration. The major finding of our study is that central administration of low-dose (i.e. $1 \%$ of the systemic dose) $\mathrm{T}_{1} \mathrm{AM}$ acutely increases EGP and plasma glucose concentration to a similar - or even greater - extent compared with systemic $\mathrm{T}_{1} \mathrm{AM}$, concomitant with an increase in plasma glucagon and corticosterone concentrations. Similar effects were observed following central $\mathrm{T}_{0} \mathrm{AM}$ infusion, albeit to a lesser extent. When administered intravenously, the same low dose of $\mathrm{T}_{1} \mathrm{AM}$ and $\mathrm{T}_{0} \mathrm{AM}$, which was effective centrally, had no detectable effect on plasma glucose or EGP; thus excluding the possibility that the observed responses were the result of leakage of the centrally administered compound into the circulation and acting peripherally.

Rats infused intraperitoneally with $\mathrm{T}_{1} \mathrm{AM}$, and to a lesser extent $\mathrm{T}_{0} \mathrm{AM}$, exhibited a behavioural phenotype within minutes of administration, which was remarkably similar to the fully reversible behavioural changes reported earlier in mice (Scanlan et al. 2004, Doyle et al. 2007). In short, animals exhibited a decrease in overall locomotor activity and responsiveness to external stimuli (visual and auditory), while reflexes were preserved. Furthermore, the hyperglycemia that develops in mice (Regard et al. 2007) following thyronamine exposure also is seen in rats (Fig. 1a). Moreover, we show for the first time that the hyperglycemia induced by the thyronamines $\mathrm{T}_{1} \mathrm{AM}$ and (to a lesser extent) $\mathrm{T}_{0} \mathrm{AM}$ occurs simultaneously with a rapid (i.e. within $10 \mathrm{~min}$ ), $\sim 50 \%$ increase in EGP that was maintained for the duration of the experiment (Fig. 1b).

With respect to the systemic administration of thyronamines, there are several mechanisms that may contribute to the alterations in glucose metabolism we observed. First, plasma glucagon increases rapidly in response to systemic $\mathrm{T}_{1} \mathrm{AM}$ and $\mathrm{T}_{0} \mathrm{AM}$ administration, concomitant with the increase in plasma glucose and EGP. It was expected that the thyronamine-induced hyperglycemia (up to $22 \mathrm{mmol} / \mathrm{l}$; Fig. 1a) would provoke a considerable insulin response. However, plasma insulin did not change in spite of the overt hyperglycemia produced by either thyronamine. The plasma glucagon increase together with this inadequate insulin response is likely to be causal factors in the increase in plasma glucose and EGP induced by thyronamines. These effects on
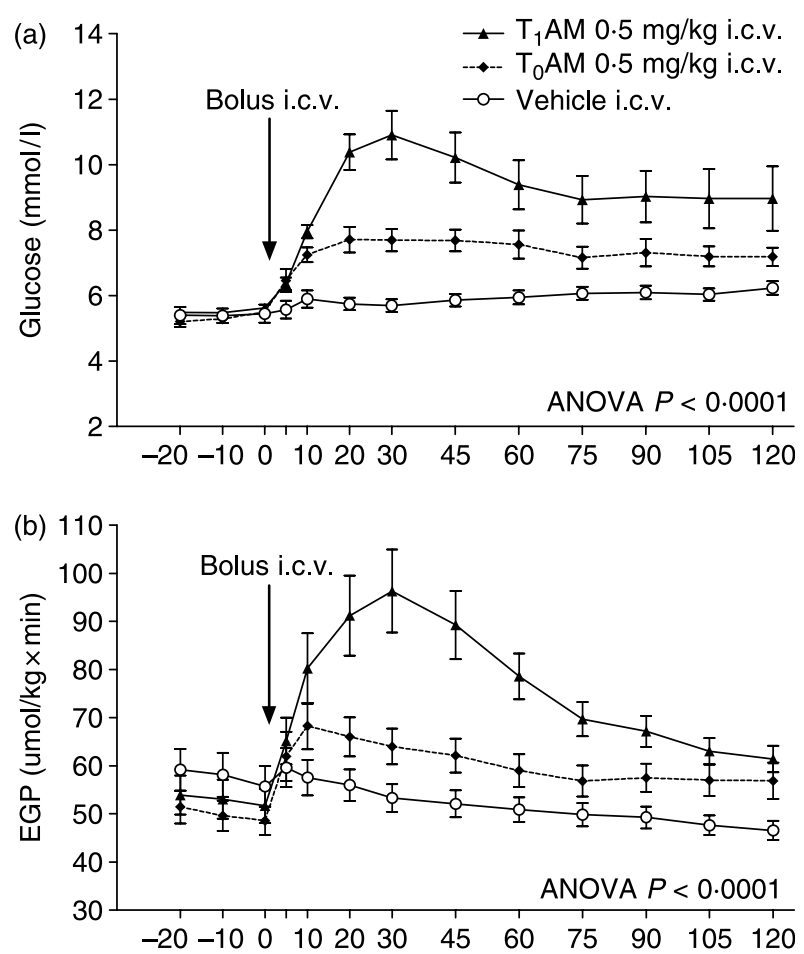

Figure 3 (a) Plasma glucose concentration before and after i.c.v. bolus infusion of $\mathrm{T}_{1} \mathrm{AM}, \mathrm{T}_{0} \mathrm{AM}$, or vehicle. From $t=5$ and $t=10$, glucose concentration in $\mathrm{T}_{1} \mathrm{AM}$ - and $\mathrm{T}_{0} \mathrm{AM}$-infused rats respectively is higher compared with vehicle rats $(P<0 \cdot 05)$. From $t=10$, glucose concentration in $T_{1} A M$-infused rats is higher relative to $T_{0} A M$ infused rats $(P<0 \cdot 05)$. ANOVA RM factor time $P<0 \cdot 0001$, time $\times$ group $P<0 \cdot 0001$, and group $P<0 \cdot 0001$. (b) Endogenous glucose production (EGP) before and after i.c.v. bolus infusion of $\mathrm{T}_{1} \mathrm{AM}, \mathrm{T}_{0} \mathrm{AM}$, or vehicle. There is no significant difference between basal samples of any group. From $t=10, \mathrm{EGP}$ in $\mathrm{T}_{1} \mathrm{AM}$-infused rats is higher compared with vehicle rats $(P<0 \cdot 05)$. In $\mathrm{T}_{0} \mathrm{AM}$ rats, EGP at $t=30,45,90,105$, and $120 \mathrm{~min}$ is higher relative to vehicle-infused rats $(P<0 \cdot 05)$. From $t=20$ to $t=90, \mathrm{EGP}$ is higher in $\mathrm{T}_{1} \mathrm{AM}$ relative to $\mathrm{T}_{0} \mathrm{AM}$-infused rats $(P<0 \cdot 05)$. ANOVA RM factor time $P<0 \cdot 0001$, time $\times$ group $P<0 \cdot 0001$, and group $P=0 \cdot 006$. 

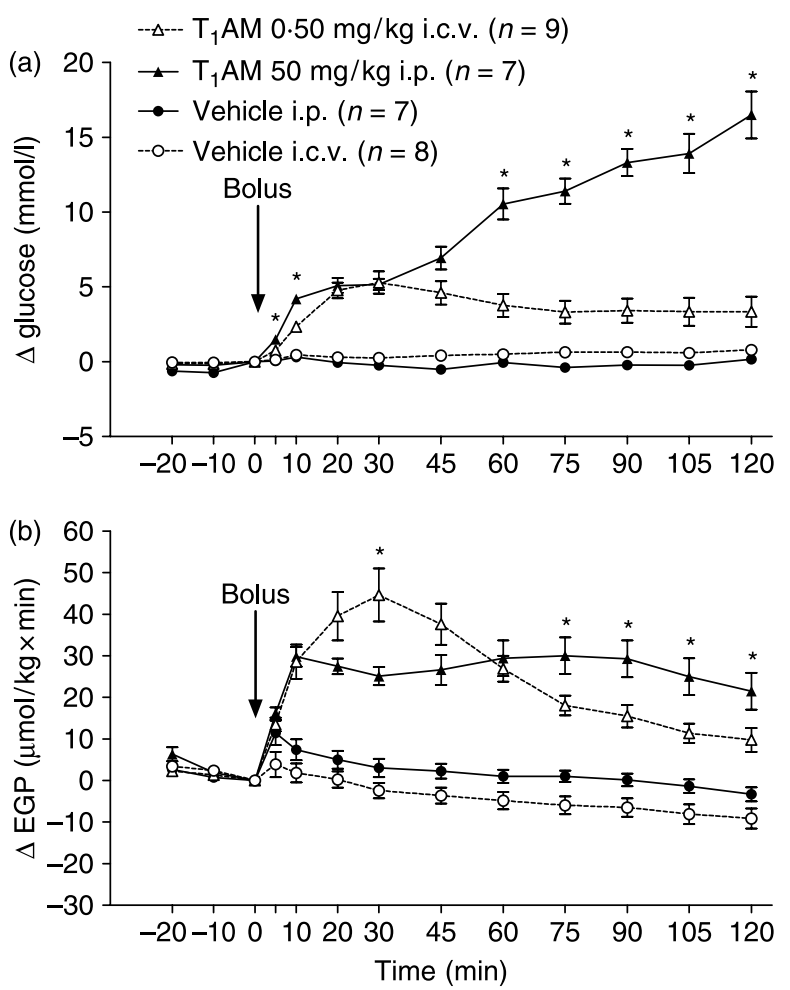

Figure 4 (a) Changes in plasma glucose concentration (delta) before and after i.p. versus i.c.v. bolus infusion of $\mathrm{T}_{1} \mathrm{AM}\left(\mathrm{T}_{1} \mathrm{AM}\right.$ i.p. and $\mathrm{T}_{1} \mathrm{AM}$ i.c.v.) or vehicle (Veh i.p. and Veh i.c.v). From $t=5$, glucose concentration in $\mathrm{T}_{1} \mathrm{AM}$ i.p. and $\mathrm{T}_{1} \mathrm{AM}$ i.c.v. groups is increased relative to the respective vehicle group. Note that on $t=20,30$, and 45 min, glucose concentration in $T_{1} A M$ i.p. and $T_{1} A M$ i.c.v. rats is not different. The changes in plasma glucose concentration are expressed as the difference compared to the plasma glucose concentration at $t=0 \mathrm{~min}$ for each individual animal. ANOVA RM factor time $P<0 \cdot 0001$, time $\times$ group $P<0 \cdot 0001$, and group $P<0 \cdot 0001$. ${ }^{*} P<0 \cdot 05 ; \mathrm{T}_{1} \mathrm{AM}$ i.p. versus $\mathrm{T}_{1} \mathrm{AM}$ i.c.v. (b) Changes in endogenous glucose production (EGP) before and after i.p. versus i.c.v. bolus infusion of $T_{1} A M\left(T_{1} A M\right.$ i.p. and $T_{1} A M$ i.c.v.) or vehicle (Veh i.p. and Veh i.c.v). From $t=5$ and $t=10 \mathrm{~min}$, EGP in $\mathrm{T}_{1} \mathrm{AM}$ i.c.v.- and $T_{1} A M$ i.p.-infused rats respectively is increased when compared with respective vehicle groups $(P<0 \cdot 05)$. Note that on $t=30$, EGP is higher in $\mathrm{T}_{1} \mathrm{AM}$ i.c.v. than in $\mathrm{T}_{1} \mathrm{AM}$ i.p.-treated rats $\left({ }^{*} P<0 \cdot 05\right)$. The changes in EGP are expressed as the difference compared to EGP at $t=0 \mathrm{~min}$ for each individual animal. ANOVA RM factor time $P<0 \cdot 0001$, time $\times$ group $P<0 \cdot 0001$, and group $P<0 \cdot 0001$.

plasma glucagon and insulin might be explained by direct actions of $T_{1} A M$ and $T_{0} A M$ on the pancreatic $\alpha$ and $\beta$-cells, supposedly by binding to GPCRs such as TAAR 1 or AR $\alpha 2$ (Liggett 2004, Scanlan et al. 2004) Indeed, pharmacological stimulation of $\mathrm{AR} \alpha 2$ has been shown to induce hyperglycemia and inhibit insulin release (Angel et al. 1990). Second, given the rapid onset of thyronamine-induced changes, it is possible that $T_{1} A M$ and $T_{0} A M$ activation of GPCRs expressed in hepatocytes underlies the stimulation of EGP we observed, analogous to the stimulation of $\beta$-ARs by norepinephrine.
With regard to the possible mechanisms underlying the effects of centrally administered thyronamines on glucose metabolism, it is interesting that concomitant with the rapid increase in EGP (Fig. 3b), plasma insulin levels tended to decrease acutely after central administration of $0.5 \mathrm{mg} / \mathrm{kg}$ $\mathrm{T}_{1} \mathrm{AM}$ (Fig. 5a) in contrast to systemically (i.e. i.p.) administered drug. In addition, after i.c.v. infusion of $0.5 \mathrm{mg} / \mathrm{kg} \mathrm{T}_{1} \mathrm{AM}$, there was a rapid increase in plasma glucagon (Fig. 5b), which was more pronounced than the early glucagon increase after systemic thyronamine infusion. No change in EGP, plasma insulin, and glucagon levels was observed after i.v. infusion of $0.5 \mathrm{mg} / \mathrm{kg} \mathrm{T}$ AM, confirming that $\mathrm{T}_{1} \mathrm{AM}$-imposed actions on the CNS are causal to these phenomena. This dependence of thyronamine effects on the route of administration point to neural or (neuro)transmitter type, rather than humoral type of actions. Indeed, it has been demonstrated that $\mathrm{T}_{1} \mathrm{AM}$ modulates synaptosomal transport of neurotransmitters such as dopamine and norepinephrine (Snead et al. 2007), supposedly by behaving as endogenous monoamine reuptake inhibitors (Weatherman 2007). In addition, low-dose $T_{1} A M$ administration in the lateral cerebral ventricles and in the arcuate nucleus was recently reported to rapidly increase food intake (Dhillo et al. 2008). The effects of thyronamines on plasma insulin and glucagon in the present study may be explained by increased sympathetic tone in the pancreas, mediated via central thyronamine actions. In addition, centrally administered thyronamines might stimulate autonomic outflow from the hypothalamus to the liver thereby elevating EGP. In support of this conjecture is accumulating evidence demonstrating the brain's important role, particularly the hypothalamus, in regulating hepatic glucose metabolism via sympathetic and parasympathetic projections to the liver (Obici et al. 2002, Kalsbeek et al. 2004, Pocai et al. 2005, Klieverik et al. 2008).

As thyronamines have been hypothesized to constitute a novel aspect of TH biology (Liggett 2004, Scanlan et al. 2004), it was of interest to assess how thyroid-related parameters in euthyroid animals responded to synthetic thyronamines. Systemic infusion of these compounds, in particular $\mathrm{T}_{0} \mathrm{AM}$, depressed plasma TSH, $\mathrm{T}_{4}$, and $\mathrm{T}_{3}$ levels, whereas central administration had no such effect. These responses could represent a state reminiscent of the non-thyroidal illness syndrome (Fliers et al. 1997, Boelen et al. 2004, Adler \& Wartofsky 2007). Although it is conceivable that the thyronamines altered $\mathrm{TH}$ secretion by decreasing $\mathrm{TSH}$ release from the pituitary, the observation that central thyronamine administration does not induce plasma $\mathrm{TH}$ alterations relative to vehicle, argues against this possibility. Finally, an effect of thyronamines on plasma concentrations of iodothyronines via interaction with the deiodinase enzymes seems less likely as $\mathrm{T}_{1} \mathrm{AM}$ does not interfere with D1-mediated iodothyronine deiodination in vitro (Piehl et al. 2008).

Systemic thyronamine administration produced significant increases in plasma corticosterone levels that were similar in $\mathrm{T}_{1} \mathrm{AM}$ - and $\mathrm{T}_{0} \mathrm{AM}$-infused rats (Fig. 2c), and could be recapitulated by low-dose $(0.5 \mathrm{mg} / \mathrm{kg})$ i.c.v. infusion of 
synthetic $T_{1} A M$ or $T_{0} A M$ (Fig. $5 c$ ), suggesting that these represent central effects of thyronamines on the hypothalamus-pituitary-adrenal axis. The elevated corticosterone could contribute in a limited way to the hyperglycemic state but, more importantly, because in both experiments the hyperglycemia was much more pronounced in $\mathrm{T}_{1} \mathrm{AM}$ when compared with $\mathrm{T}_{0} \mathrm{AM}$-infused animals, it is unlikely to account for the major glucose increase induced by systemic and central $\mathrm{T}_{1} \mathrm{AM}$.
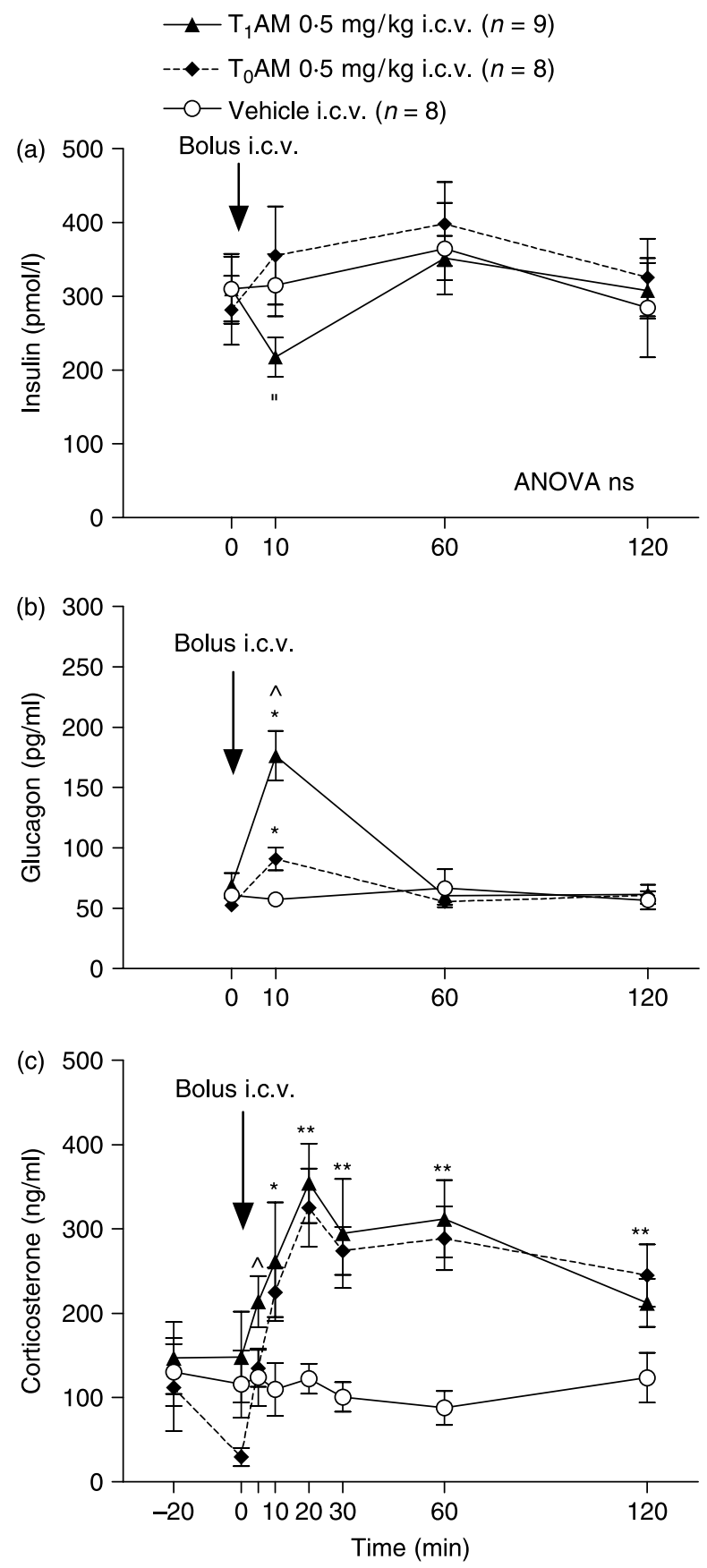

There are several mechanisms by which circulating thyronamines might exert their actions in the CNS. First, there could be passive or active transport of circulating thyronamines across the blood-brain barrier, the latter analogous to iodothyronines (Dratman et al. 1991). Second, circulating thyronamines might bind cell-surface receptors in the plasma membrane of neurons located in circumventricular nuclei such as the arcuate nucleus where the blood-brain barrier is absent. The arcuate nucleus is known to mediate central actions of the peptide hormones like insulin and leptin via locally expressed leptin and insulin receptors (Niswender \& Schwartz 2003), and TAAR1 is expressed in the arcuate nucleus (Borowsky et al. 2001). However, our finding that the EGP increase is not as robust following central administration of thyronamines as it is after systemic administration suggests their central actions alone are insufficient to account for the persistent EGP increase and hyperglycemia. Consistent with this interpretation are the results from a recent study in which mice pre-treatment with 6-hydroxydopamine still developed hyperglycemia and hypoinsulinemia following i.p. administration of $T_{1} A M$, suggesting that these $T_{1} A M$-induced alterations can occur in the absence of sympathetic signalling (Regard et al. 2007). Another possibility is that thyronamines impose both peripheral and central actions on glucose metabolism, occurring independently. In this intriguing scenario, central actions could be mediated by thyronamines formed locally in the brain, by conversion from iodothyronines such as $T_{4}, T_{3}$, and/or reverse $T_{3}$.

The rapid and pronounced metabolic effects produced by central administration of $\mathrm{T}_{1} \mathrm{AM}$ and $\mathrm{T}_{0} \mathrm{AM}$ suggest that one or more receptors mediate their actions. Indeed, $\mathrm{T}_{1} \mathrm{AM}$ and $\mathrm{T}_{0} \mathrm{AM}$ dose dependently activate the Gs protein-coupled TAAR1 receptor (Borowsky et al. 2001, Bunzow et al. 2001, Grandy 2007, Wainscott et al. 2007). TAAR1 belongs to a large family of related receptors (Borowsky et al. 2001, Grandy 2007), and this receptor's mRNA is expressed in a wide variety of tissues including many areas of the brain

Figure 5 (a) Plasma insulin concentrations before $(t=0)$ and after i.c.v. bolus infusion of $\mathrm{T}_{1} \mathrm{AM}, \mathrm{T}_{0} \mathrm{AM}$, or vehicle. Note that at $t=10 \mathrm{~min}$, there is a trend for insulin concentrations to be depressed in animals receiving $0.5 \mathrm{mg} / \mathrm{kg} \mathrm{T}_{1} \mathrm{AM}$ i.c.v. compared with vehicle-treated rats (" $P=0 \cdot 063)$. ANOVA RM factor time $P=0 \cdot 01$, time $\times$ group $P=0 \cdot 161$, and group $P=0 \cdot 758$. (b) Plasma glucagon concentrations before $(t=0)$ and after i.c.v. bolus infusion of $\mathrm{T}_{1} \mathrm{AM}, \mathrm{T}_{0} \mathrm{AM}$, or vehicle. At $t=10 \mathrm{~min}$, glucagon is significantly higher in $\mathrm{T}_{1} \mathrm{AM}$ i.c.v. and, to a lesser extent, $\mathrm{T}_{0} \mathrm{AM}$ i.c.v. when compared with vehicle i.c.v.-treated rats. ${ }^{*} P<0 \cdot 01$ versus vehicle i.c.v., ${ }^{\wedge} P<0 \cdot 01 \mathrm{~T}_{1} \mathrm{AM}$ versus $\mathrm{T}_{0} \mathrm{AM}$ i.c.v. ANOVA RM factor time $P<0.0001$, time $\times$ group $P<0.0001$, and group $P<0.0001$. (c) Plasma corticosterone concentration before $(t=-20$ and $0 \mathrm{~min})$ and after ( $t=5$ to $t=120 \mathrm{~min}$ ) i.c.v. bolus infusion of $\mathrm{T}_{1} \mathrm{AM}, \mathrm{T}_{0} \mathrm{AM}$, or vehicle. Circulating corticosterone levels rapidly increase following the infusion of $\mathrm{T}_{1} \mathrm{AM}$ or $\mathrm{T}_{0} \mathrm{AM}$ at $t=20$ and $t=10 \mathrm{~min}$ when compared with vehicle respectively. Note that $T_{1} A M-$ and $\mathrm{T}_{0} \mathrm{AM}$ i.c.v.-infused groups do not differ at any time point, except for $t=5$ min. ${ }^{*} P<0.05$ versus vehicle i.c.v., ${ }^{\wedge} P<0.01 \mathrm{~T}_{1} \mathrm{AM}$ versus $\mathrm{T}_{0} \mathrm{AM}$ i.c.v. ANOVA RM factor time $P<0 \cdot 0001$, time $\times$ group $P=0 \cdot 002$, and group $P=0 \cdot 001$. 
Table 2 Plasma thyroid hormone concentrations before (basal) and after ( 2 h) i.c.v. vehicle, $\mathrm{T}_{1} \mathrm{AM}$, and $\mathrm{T}_{0} \mathrm{AM}$ infusion

\begin{tabular}{|c|c|c|c|c|c|c|c|c|c|}
\hline & \multicolumn{2}{|c|}{ Veh i.c.v. $n=8$} & \multicolumn{2}{|c|}{$\mathbf{T}_{\mathbf{1}} \mathbf{A M}$ i.c.v. $n=9$} & \multicolumn{2}{|c|}{$\mathbf{T}_{\mathbf{0}} \mathbf{A M}$ i.c.v. $n=8$} & \multicolumn{3}{|c|}{ ANOVA RM } \\
\hline & Basal & $2 \mathrm{~h}$ & Basal & $2 \mathrm{~h}$ & Basal & $2 \mathrm{~h}$ & Time & $\begin{array}{l}\text { Time } \times \\
\quad \text { group }\end{array}$ & Group \\
\hline & & & & & & & $P$ & $P$ & $P$ \\
\hline $\mathrm{T}_{3}(\mathrm{nmol} / \mathrm{l})$ & $1 \cdot 27 \pm 0 \cdot 08$ & $0 \cdot 77 \pm 0 \cdot 05^{*}$ & $1 \cdot 39 \pm 0 \cdot 15$ & $0 \cdot 86 \pm 0 \cdot 09 *$ & $1 \cdot 00 \pm 0 \cdot 05$ & $0.73 \pm 0.05^{*}$ & $0 \cdot 0001$ & $0 \cdot 198$ & $0 \cdot 056$ \\
\hline $\mathrm{T}_{4}(\mathrm{nmol} / \mathrm{l})$ & $81 \pm 7$ & $53 \pm 4^{*}$ & $79 \pm 7$ & $64 \pm 7^{*}$ & $87 \pm 4$ & $62 \pm 4^{*}$ & $0 \cdot 0001$ & $0 \cdot 184$ & $0 \cdot 578$ \\
\hline $\mathrm{TSH}(\mathrm{mU} / \mathrm{l})$ & $1 \cdot 64 \pm 0.33$ & $0 \cdot 77 \pm 0 \cdot 16^{*}$ & $1 \cdot 36 \pm 0 \cdot 26$ & $0.64 \pm 0.19$ & $1 \cdot 65 \pm 0.25$ & $0 \cdot 58 \pm 0 \cdot 10^{*}$ & $0 \cdot 0001$ & $0 \cdot 665$ & $0 \cdot 734$ \\
\hline
\end{tabular}

$* P \leq 0.05$ versus basal value within the same group.

(Borowsky et al. 2001, Bunzow et al. 2001). The fact that the rank order of potency as a TAAR 1 agonist in vitro, $\mathrm{T}_{1} \mathrm{AM}$ being more potent than $\mathrm{T}_{0} \mathrm{AM}$ (Scanlan et al. 2004), is also reflected in the metabolic responses described in the present study, fits with the notion that TAAR 1 may mediate some actions of $T_{1} A M$ and $T_{0} A M$. In addition, Regard et al. (2007) have recently shown that whereas $T_{1} A M$ induces hyperglycemia after systemic administration in wild-type mice, this effect is lost in AR $\alpha 2$-deficient mice as well as mice pretreated with the AR $\alpha 2$ antagonist yohimbine. Moreover, by using a transgenic approach, they provided strong evidence that the hyperglycemia and concurrent hypoinsulinemia following $\mathrm{T}_{1} \mathrm{AM}$ infusion in mice was dependent upon pancreatic Gi protein-coupled receptor expression. Collectively, these data suggest that, at least for the effects of systemically administered $\mathrm{T}_{1} \mathrm{AM}$ on glucose metabolism, $\mathrm{AR} \alpha 2$ is important. Interestingly, $\mathrm{AR} \alpha 2$ are highly expressed in the hypothalamus as well and contribute to the hypothalamic regulation of sympathetic outflow (Li et al. 2005), supporting their possible involvement in mediating effects of centrally administered thyronamines.

To date, every published metabolic and physiologic study involving thyronamines, including this one, has relied on the administration of synthetic material (Braulke et al. 2007, Chiellini et al. 2007, Doyle et al. 2007, Regard et al. 2007). Therefore, the biological significance of endogenous thyronamines remains to be addressed. In this context, it will be important to establish how and where these compounds are synthesized. Although there is currently no direct evidence in the literature for in vivo conversion of thyronamines from precursor iodothyronines (i.e. $\mathrm{T}_{3}, \mathrm{~T}_{4}$, and $\mathrm{rT}_{3}$ ), the enzymes indispensable for such conversion such as aromatic amino acid decarboxylase for decarboxylation and iodothyronine deiodinases type 2 and 3 for deiodination are widely distributed in the CNS, and indeed within the hypothalamus (Zhu \& Juorio 1995, Tu et al. 1997, Alkemade et al. 2005, Lechan \& Fekete 2005). An important remaining question is whether the metabolic effects in the present and other studies represent physiological or pharmacological effects of thyronamines. The systemic dose of $\mathrm{T}_{1} \mathrm{AM}$ used in our study has been shown to induce a tenfold increase in plasma $T_{1} A M$ concentration within $3 \mathrm{~h}$ after infusion in Siberian hamsters (Braulke et al. 2007). However, there are currently no data on the pharmacokinetic characteristics (distribution volume, clearance, and binding to plasma proteins) of thyronamines, and at present it is unknown how thyronamine tissue concentrations during experimental manipulations compare to their concentrations under more physiologic conditions.

We conclude that central administration of a low dose of either $\mathrm{T}_{1} \mathrm{AM}$ or $\mathrm{T}_{0} \mathrm{AM}$ can acutely induce increased EGP and hyperglycemia, concomitant with increased plasma glucagon, corticosterone, and a deficient insulin response. These changes are very similar to the acute changes observed after systemic $\mathrm{T}_{1} \mathrm{AM}$ and $\mathrm{T}_{0} \mathrm{AM}$ administration. Our data indicate that thyronamines can act centrally in order to modulate glucose metabolism.

\section{Declaration of interest}

The authors declare that there is no conflict of interest that could be perceived as prejudicing the impartiality of the research reported.

\section{Funding}

This research did not receive any specific grant from any funding agency in the public, commercial, or not-for-profit sector.

\section{Acknowledgements}

We wish to thank A van Riel, E M Johannesma-Brian, and A F C Ruiter for their excellent technical assistance.

\section{References}

Ackermans MT, Pereira Arias AM, Bisschop PH, Endert E, Sauerwein HP \& Romijn JA 2001 The quantification of gluconeogenesis in healthy men by (2) $\mathrm{H}_{2} \mathrm{O}$ and [2-(13) Clglycerol yields different results: rates of gluconeogenesis in healthy men measured with $(2) \mathrm{H}_{2} \mathrm{O}$ are higher than those measured with [2-(13)C]glycerol. Journal of Clinical Endocrinology and Metabolism 86 2220-2226.

Ackermans MT, Klieverik LP, Endert E, Sauerwein HP, Kalsbeek A \& Fliers E 2008 Plasma insulin concentrations during a hyperinsulinaemic clamp: what do we measure? Annals of Clinical Biochemistry 45 429-430.

Adler SM \& Wartofsky L 2007 The nonthyroidal illness syndrome. Endocrinology and Metabolism Clinics of North America 36 657-672. 
Alkemade A, Friesema EC, Unmehopa UA, Fabriek BO, Kuiper GG, Leonard JL, Wiersinga WM, Swaab DF, Visser TJ \& Fliers E 2005 Neuroanatomical pathways for thyroid hormone feedback in the human hypothalamus. Journal of Clinical Endocrinology and Metabolism 154 491-500.

Angel I, Niddam R \& Langer SZ 1990 Involvement of alpha-2 adrenergic receptor subtypes in hyperglycemia. Journal of Pharmacology and Experimental Therapentics 254 877-882.

Boelen A, Kwakkel J, Thijssen-Timmer DC, Alkemade A, Fliers E \& Wiersinga WM 2004 Simultaneous changes in central and peripheral components of the hypothalamus-pituitary-thyroid axis in lipopolysaccharide-induced acute illness in mice. Journal of Endocrinology 182 315-323.

Borowsky B, Adham N, Jones KA, Raddatz R, Artymyshyn R, Ogozalek KL, Durkin MM, Lakhlani PP, Bonini JA, Pathirana S et al. 2001 Trace amines: identification of a family of mammalian $G$ protein-coupled receptors. PNAS 98 8966-8971.

Braulke LJ, Klingenspor M, Debarber A, Tobias SC, Grandy DK, Scanlan TS \& Heldmaier G 2007 3-Iodothyronamine: a novel hormone controlling the balance between glucose and lipid utilisation. Journal of Comparative Physiology 178 167-177.

Bunzow JR, Sonders MS, Arttamangkul S, Harrison LM, Zhang G, Quigley DI, Darland T, Suchland KL, Pasumamula S, Kennedy JL et al. 2001 Amphetamine, 3,4-methylenedioxymethamphetamine, lysergic acid diethylamide, and metabolites of the catecholamine neurotransmitters are agonists of a rat trace amine receptor. Molecular Pharmacology 60 1181-1188.

Chiellini G, Frascarelli S, Ghelardoni S, Carnicelli V, Tobias SC, Debarber A, Brogioni S, Ronca-Testoni S, Cerbai E, Grandy DK et al. 2007 Cardiac effects of 3-iodothyronamine: a new aminergic system modulating cardiac function. FASEB Journal 21 1597-1608.

Dhillo WS, Bewick GA, White NE, Gardiner JV, Thompson EL, Bataveljic A, Murphy KG, Roy D, Patel NA, Scutt JN et al. 2008 The thyroid hormone derivative 3-iodothyronamine increases food intake in rodents. Diabetes, Obesity and Metabolism 11 251-260.

Doyle KP, Suchland KL, Ciesielski TM, Lessov NS, Grandy DK, Scanlan TS \& Stenzel-Poore MP 2007 Novel thyroxine derivatives, thyronamine and 3-iodothyronamine, induce transient hypothermia and marked neuroprotection against stroke injury. Stroke 38 2569-2576.

Dratman MB, Crutchfield FL \& Schoenhoff MB 1991 Transport of iodothyronines from bloodstream to brain: contributions by blood:brain and choroid plexus:cerebrospinal fluid barriers. Brain Research 554 229-236.

Fliers E, Guldenaar SE, Wiersinga WM \& Swaab DF 1997 Decreased hypothalamic thyrotropin-releasing hormone gene expression in patients with nonthyroidal illness. Journal of Clinical Endocrinology and Metabolism 82 4032-4036.

Grandy DK 2007 Trace amine-associated receptor 1-family archetype or iconoclast? Pharmacology and Therapeutics 116 355-390.

Hart ME, Suchland KL, Miyakawa M, Bunzow JR, Grandy DK \& Scanlan TS 2006 Trace amine-associated receptor agonists: synthesis and evaluation of thyronamines and related analogues. Journal of Medicinal Chemistry 49 1101-1112.

Kalsbeek A, Fliers E, Franke AN, Wortel J \& Buijs RM 2000 Functional connections between the suprachiasmatic nucleus and the thyroid gland as revealed by lesioning and viral tracing techniques in the rat. Endocrinology 141 3832-3841.

Kalsbeek A, La FS, Van HC \& Buijs RM 2004 Suprachiasmatic GABAergic inputs to the paraventricular nucleus control plasma glucose concentrations in the rat via sympathetic innervation of the liver. Journal of Neuroscience $\mathbf{2 4}$ 7604-7613
Klieverik LP, Sauerwein HP, Ackermans M, Boelen A, Kalsbeek A \& Fliers E 2008 Effects of thyrotoxicosis and selective hepatic autonomic denervation on hepatic glucose metabolism in rats. American Journal of Physiology. Endocrinology and Metabolism 294 513-520.

Lechan RM \& Fekete C 2005 Role of thyroid hormone deiodination in the hypothalamus. Thyroid 15 883-897.

Li DP, Atnip LM, Chen SR \& Pan HL 2005 Regulation of synaptic inputs to paraventricular-spinal output neurons by alpha2 adrenergic receptors. Journal of Neurophysiology 93 393-402.

Liggett SB 2004 The two-timing thyroid. Nature Medicine 10 582-583.

Niswender KD \& Schwartz MW 2003 Insulin and leptin revisited: adiposity signals with overlapping physiological and intracellular signaling capabilities. Frontiers in Neuroendocrinology 24 1-10.

Obici S, Zhang BB, Karkanias G \& Rossetti L 2002 Hypothalamic insulin signaling is required for inhibition of glucose production. Nature Medicine 8 1376-1382.

Piehl S, Heberer T, Balizs G, Scanlan TS, Smits R, Koksch B \& Kohrle J 2008 Thyronamines are isoenzyme specific substrates of deiodinases. Endocrinology 149 3037-3049.

Pocai A, Lam TK, Gutierrez-Juarez R, Obici S, Schwartz GJ, Bryan J, Aguilar-Bryan L \& Rossetti L 2005 Hypothalamic K(ATP) channels control hepatic glucose production. Nature 434 1026-1031.

Regard JB, Kataoka H, Cano DA, Camerer E, Yin L, Zheng YW, Scanlan TS, Hebrok M \& Coughlin SR 2007 Probing cell type-specific functions of $\mathrm{G}(\mathrm{i})$ in vivo identifies GPCR regulators of insulin secretion. Journal of Clinical Investigation 117 4034-4043.

Scanlan TS, Suchland KL, Hart ME, Chiellini G, Huang Y, Kruzich PJ, Frascarelli S, Crossley DA, Bunzow JR, Ronca-Testoni S et al. 2004 3-Iodothyronamine is an endogenous and rapid-acting derivative of thyroid hormone. Nature Medicine 10 638-642.

Snead AN, Santos MS, Seal RP, Miyakawa M, Edwards RH \& Scanlan TS 2007 Thyronamines inhibit plasma membrane and vesicular monoamine transport. ACS Chemical Biology 2 390-398.

Steele R 1959 Influences of glucose loading and of injected insulin on hepatic glucose output. Annals of the New York Academy of Sciences 82 420-430.

Tu HM, Kim SW, Salvatore D, Bartha T, Legradi G, Larsen PR \& Lechan RM 1997 Regional distribution of type 2 thyroxine deiodinase messenger ribonucleic acid in rat hypothalamus and pituitary and its regulation by thyroid hormone. Endocrinology 138 3359-3368.

Wainscott DB, Little SP, Yin T, Tu Y, Rocco VP, He JX \& Nelson DL 2007 Pharmacologic characterization of the cloned human trace amine-associated receptor1 (TAAR1) and evidence for species differences with the rat TAAR1. Journal of Pharmacology and Experimental Therapeutics 320 475-485.

Weatherman RV 2007 A triple play for thyroid hormone. ACS Chemical Biology 2 377-379.

Zhu MY \& Juorio AV 1995 Aromatic L-amino acid decarboxylase: biological characterization and functional role. General Pharmacology 26 681-696.

Received in final form 26 February 2009
Accepted 6 March 2009
Made available online as an Accepted Preprint
6 March 2009

